УДК 621.311.01

B. В. Зорін, д-р техн. наук, проф.;ORCID 0000-0001-5913-401X Ю. М. Мацкевич, магістр, ORCID 0000-0002-1095-3791,

Національний технічний університет України «Київський політехнічний інститут імені Ігоря Сікорського» КОМПЕНСАЦІЯ РЕАКТИВНОЇ ПОТУЖНОСТІ У СТОЯКАХ ВИСОТНИХ БУДІВЕЛЬ

Розроблено метод визначення місиь установки і потужності батарей конденсаторів на основі даних вимірювань втрат напруги на характерних ділянках схеми електричної мережі. Наведено алгоритм розрахунку таких параметрів режиму, як втрати активної потужності $\triangle P$ і реактивної потужності $\triangle Q$ в електричній мережі 0,38 кB будинків висотної забудови міста. Розглянуто приклад розрахунку для багатоповерхового будинку даним методом. Переваги запропонованого методу визначення місиь установки і потужності батарей конденсаторів це простота і можливість компенсувати реактивну потужність безпосередньо у побутових споживачів.

Ключові слова: розрахункова схема, параметри режимів, компенсація реактивної потужності, конденсаторні батареї, втрати потужності, втрати напруги.

Надійшла 25.01.2018

Received 25.01.2018

УДК 697.112.2

P.В. Мордас, магістрант

Л.Н.Лебедь, к.т.н., доцент

Національний технічний університет України «Київський політехнічний інститут імені Ігоря Сікорського»

\title{
МОДЕЛЮВАННЯ ТЕПЛОВОГО СТАНУ БУДІВЛІ 3 СИСТЕМОЮ ТЕРМОАКТИВНОГО УТЕПЛЕННЯ
}

В статті описано нову систему теплозабезпечення, щчо може використовуватися як для нових будинків, так і для реконструкиії старих будівель, де система опалення вже вичерпала свій ресурс $і$ не підлягає відновленню. Розгянуто систему термоактивного утеплення опалення та охолодження, основними перевагами якої є робота з низькотемпературними джерелами теплоти (теплові насоси, сонячні колектори та ін.) Запропоновано теплогідравлічну схему роботи даної системи в поєднанні 3 інноваційним обладанням. Проведено CFD моделювання температурного режиму поточної частини корпусу теплоенергетичного факультету КПІ ім. Ігоря Сікорського. Отримано температурні поля та розподіли швидкості повітря в приміщенні, витрати теплової енергї для опалення приміщення в двох випадках: до термодернізачії та після ї̈ виконання. У зв'язку із збільшеною ефективністю роботи теплових насосів в низькотемпературному режимі маємо різницю у витраті енергії на підтримання температурного стану будівлі в 8 разів. Характерною особливістю даної системи також є можливість роботи в режимі кондиціонування приміщень.

Ключові слова: термоактивні конструкції, термоактивне утеплення, система теплозабезпечення, температурний стан будівель, тепловий насос.

(C) Р.В. Мордас, Л.Н.Лебедь, 2018 
Вступ. В контексті постійного підвищення цін на енергоресурси постає питання найефективнішого використання останніх. При цьому, витрати на підтримання оптимального температурного рівня об’єктів зростають. Аналіз втрат енергії первинного палива свідчить про те, що найбільші надлишкові втрати теплоти відбуваються у її кінцевих споживачів, тобто в будівлях. Тому постають задачі організації енергозберігаючих режимів експлуатації будівлі, пошуку і реалізації інноваційних рішень щодо зменшення тепловтрат (теплопритоків) та приведенню їх до відповідності діючим нормам. Відомі термоактивні будівельні системи (TABS), де елементи, які гріють, розташовані безпосередньо в бетонних елементах будівлі (зовнішні стіни, стеля, перекриття) [1]. Тобто система TABS актуальна лише для нових будівель, що проектуються. Для термомодернізації існуючих будівель цю систему застосовувати неможливо. Тому пропонується застосовувати систему термоактивного утеплення, яка монтується на фасаді вже існуючої будівлі.

Актуальність. Важливим питанням зменшення споживання енергії $\epsilon$ енергоефективність будівель. Аналіз існуючої літератури показав, що системи 3 використанням термоактивних конструкцій $\epsilon$ оптимальним рішенням при модернізації існуючих старих будівель до рівня енергопасивних категорій, а також при заміні систем опалення, які вичерпали свій ресурс. Оскільки система активного утепленняопалення охолодження компенсує тепловтрати, то необхідно оцінити температурний стан приміщень при застосуванні даних систем. Результатам рішення цієї задачі з використанням програми EnergyPlus в комплексі з DesignBuilder присвячена дана стаття.

Система теплозабезпечення будівлі. Представлена система (рис.1,2) є оптимальним рішенням для реконструкції застарілих систем опалення, оскільки немає необхідності замінювати старі системи на нові, це досить актуально для багатоповерхівок, які були збудовані (40...50) років тому. При цьому, вирішується декілька важливих питань:

1) збільшення опору теплопередачі огороджуючих конструкцій;

2) приведення будівель до існуючих норм енергоефективності;

3) забезпечення низького рівня вологості конструктивних елементів та утеплювача;

4) рівномірність розподілення теплового навантаження по будівлі (без зон перегріву);

5) нормований вологісний стан приміщень за рахунок відсутності ефекту значної дифузії вологи через огороджуючі конструкції, що дають стандартні системи обігріву; це покращуе теплоізоляційні властивості утеплювача та конструктивних матеріалів та не допускає утворення грибків;

6) підвищується теплова інерційність будівлі, що дозволяє застосовувати будинок як тепловий акумулятор для роботи системи за зниженим нічним тарифом;

7) забезпечується опалення та кондиціювання приміщення за рахунок того, що контури, які гріють, розташовуються ззовні, також виключено утворення конденсату на межі утеплювач-стінка.[2]

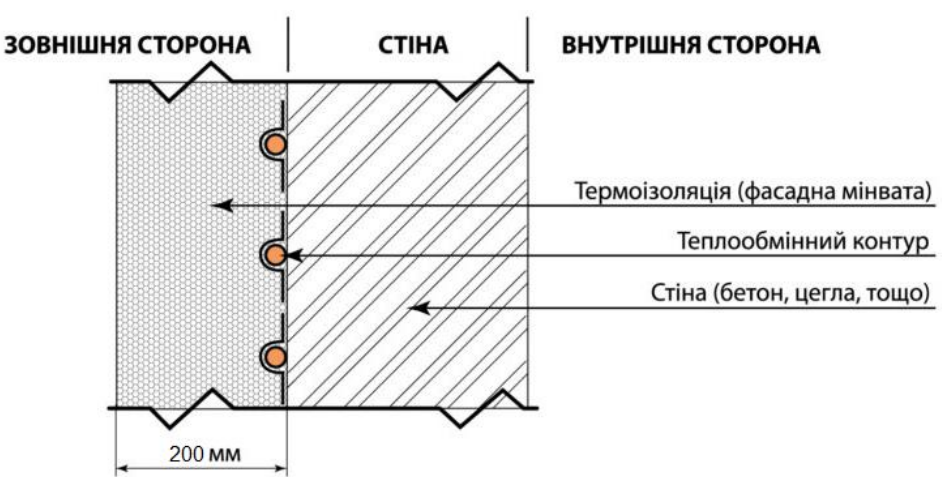

Рисунок 1 - Поперечний перетин стіни з системою термоактивного утеплення [2] $\begin{array}{llrr}\text { На рисунку } & 3 & \text { зображено } \\ \text { теплогідравлічну } & \text { схему } & \text { системи } \\ \text { термоактивного } & \text { утеплення, } \\ \text { складається } 3 & \text { теплового } & \text { насосу, }\end{array}$ буферного акумулятора теплоти, низькопотенційного джерела теплоти та вузла реверсу. Дана схема реалізує опалення та кондиціювання будівлі 3 використанням низькопотенційних джерел теплоти, Сонця. Для сталої роботи теплового насосу передбачено застосування буферного акумулятора тепла, що також дозволяє використовувати знижений нічний тариф на електроенергію. Сонячні колектори дозволяють підвищити ефективність

роботи теплового насосу за рахунок роботи на низькопотенційне джерело (в міжсезонний період), а також здійснювати прямий підігрів буферного акумулятора (в період високого показнику сонячної інсоляції). 


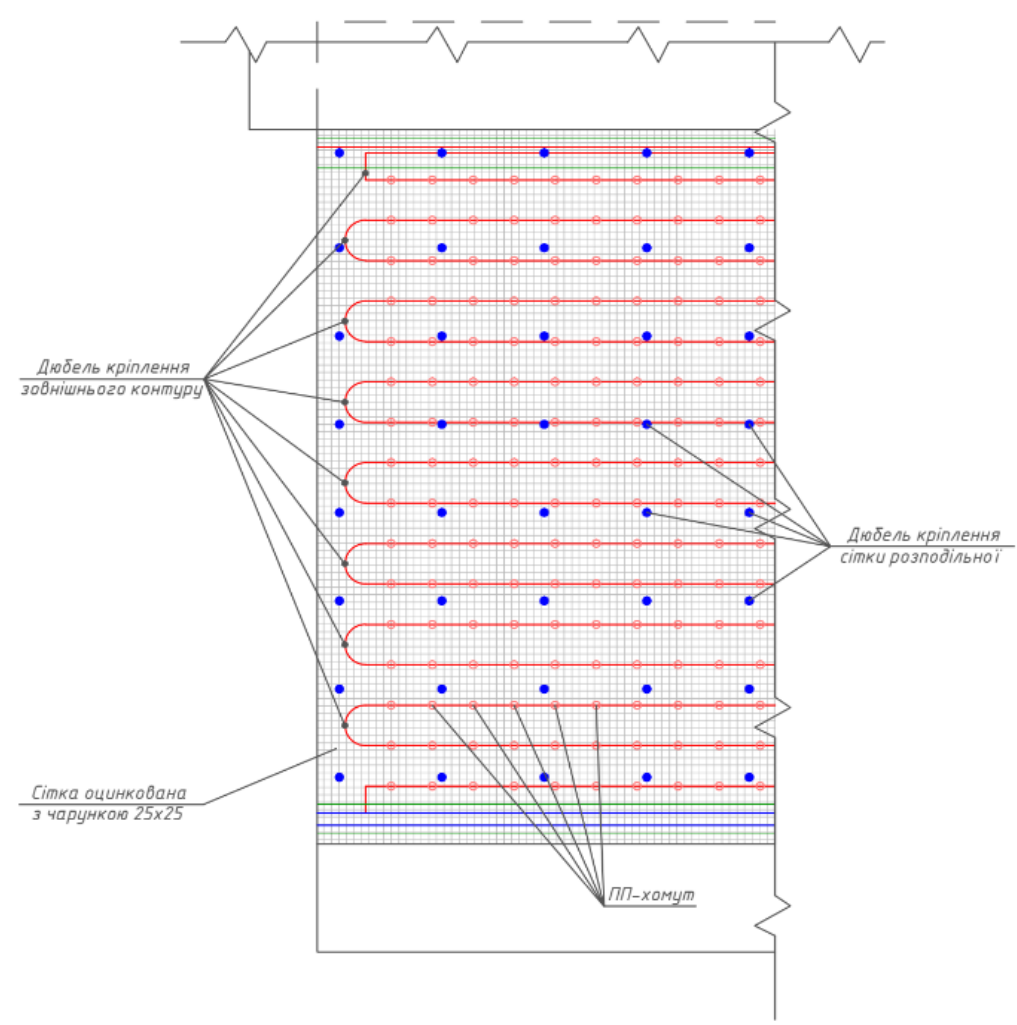

Рисунок 2 - Загальний вид системи термоактивного утеплення

У випадку застосування теплового насосу типу грунт-вода, існує можливість використання так званого «пасивного» холоду землі, тобто отримувати теплоносій з температурою $10{ }^{\circ} \mathrm{C}$ протягом певного періоду року. Що повністю є достатнім для ефективної роботи системи термоактивного утеплення в режимі охолодження.

Якщо ж в якості низькопотенційного джерела енергії використовується повітря, то можливість використання «пасивного» холоду відсутня, ефективність кондиціювання за допомогою теплового насосу зберігається на високому рівні за рахунок невеликого перепаду $\left(10 \ldots 15^{\circ} \mathrm{C}\right)$ між температурами на випарнику та конденсаторі теплового насосу. При цьому, холодильний коефіцієнт теплового насосу EER (Energy Efficiency Ratio) має значення 6...7 на відміну від застосування звичайної системи кондиціювання, де цей показник не перевищує в середньому 3,5 .

Представлена система термоактивного утеплення з альтернативними джерелами теплоти (рис. 3) передбачає відокремлення контурів, які гріють, по різним фасадам будівель. Це дозволяє змінювати температурний напір контуру в залежності від орієнтації по сторонам світу, тобто збільшити тепловий потік з північної сторони, та зменшити його за необхідності з боку можливої сонячної інсоляції (південний фасад).

При виборі методу укладання трубопроводів надають перевагу схемі руху за Тихельманом, використовуючи іiі основну перевагу - однакову витрату теплоносія в кожному контурі системи. Це дозволяє уникнути значних градієнтів температур, особливо коли застосовується реверсивна схема циркуляції з певним гістерезисом переключення, час якого для кожної будівлі визначається експериментальним шляхом.

Використання даної системи дозволяє досягти значення коефіцієнта тепловіддачі від огороджуючих конструкцій в діапазоні (5..9) Вт/( $\left.{ }^{2} \cdot{ }^{\circ} \mathrm{C}\right)$, тому доцільно застосовувати систему в будівлях із відсотком скління, що менше $50 \%$. 


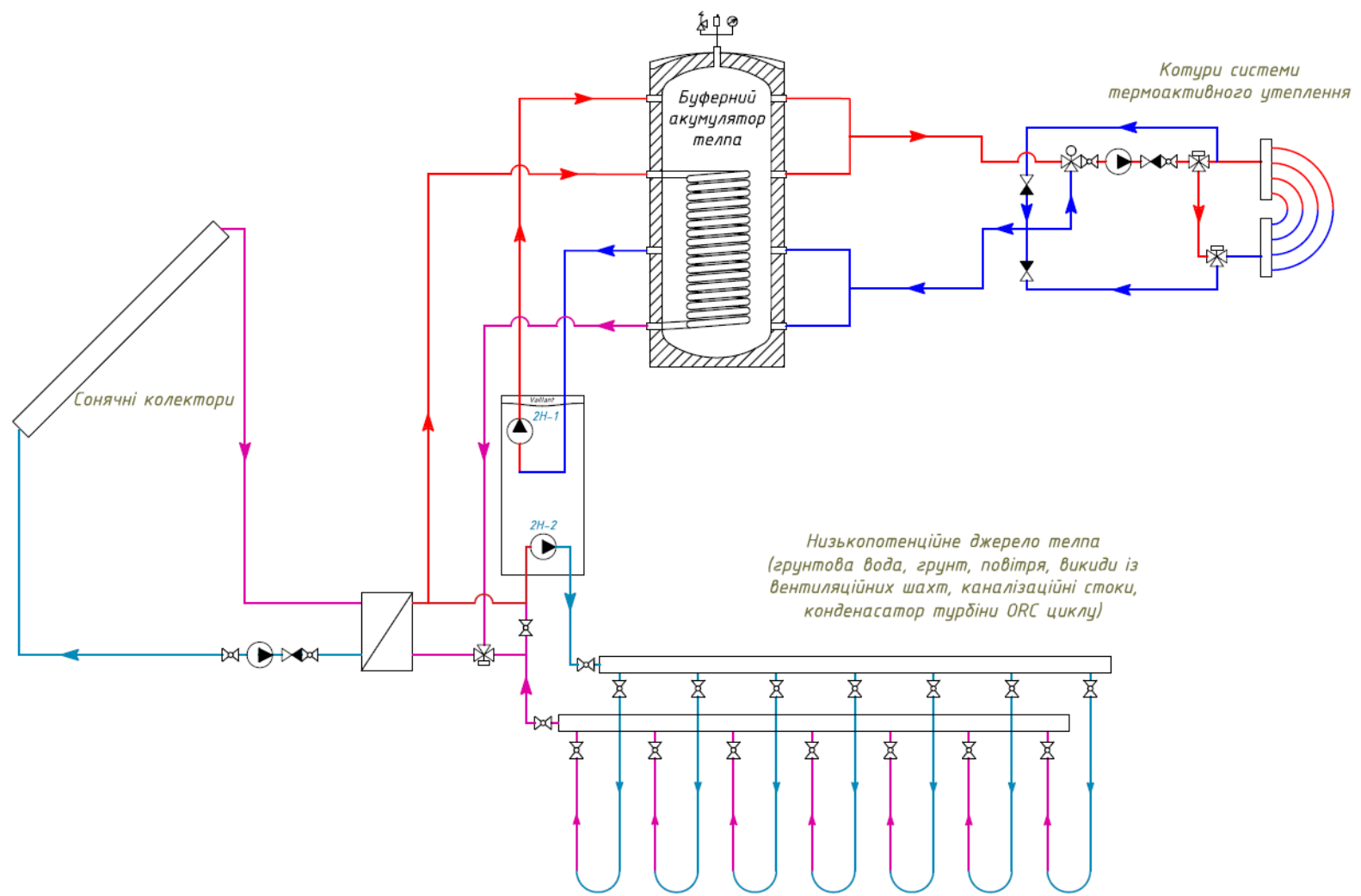

Рисунок 3 - Теплогідравлічна схема системи термоактивного утеплення із застосуванням альтернативних джерел теплоти

Вибір методу дослідження. Для отримання температурного стану будівлі було обрано чисельний метод дослідження, який дозволяє врахувати велику кількість факторів впливу на температурний стан, якісно показати цей вплив для виконання подальшого аналізу процесів і розробки ефективних систем термостабілізації. Перевагами чисельного методу $є$ низька вартість, відносна швидкість, повнота інформації, можливість математичного моделювання реальних процесів.

Опис об’ скту, шо моделюсться.

У якості об’єкту моделювання було прийнято частину корпусу № 5 (поточні аудиторії) Теплоенергетичного факультету «КПІ ім. Ігоря Сікорського». Конструктив будівлі складався 3 цементнопісчаної кладки в 200 мм, що ззовні покрита шаром цементно-піщаної штукатурки товщиною 30 мм. 3 внутрішньої сторони будівлі - гіпсова штукатурка.

Для створення системи термоактивного утеплення додається шар утеплювача 3 фасадних мінеральних плит товщиною в 200 мм.

На рисунку 3 зображено геометричну модель частини будівлі, що була об’єктом дослідження. Для побудови геометричної моделі об’єкту використовувалися кресленики будівлі. 


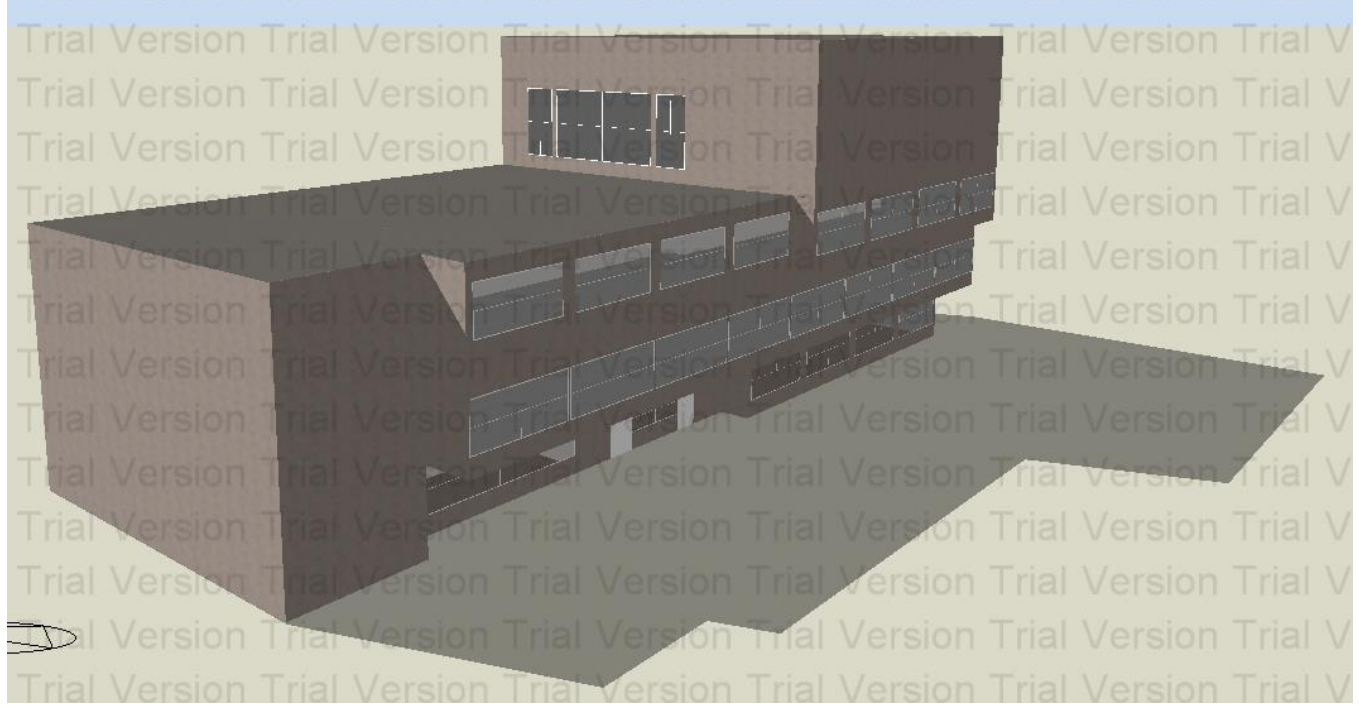

Рисунок 3 - Геометрична модель об’єкту моделювання

В таблицях 1..3 представлено розрахункові дані щодо даного типу будівлі, які обрано згідно креслеників будівлі і вимог державних будівельних норм [3].

Таблиця 1 - Розрахункові параметри об’єкту моделювання

\begin{tabular}{|l|c|}
\multicolumn{1}{|c|}{ Параметр } & Значення \\
\hline Загальна площа & $2061,3 \mathrm{~m}^{2}$ \\
\hline Об’єм & $11800 \mathrm{~m}^{3}$ \\
\hline Щільність людей & 0,2 людини/ ${ }^{2}$ \\
\hline $\begin{array}{l}\text { Людська активність } \\
\text { (коефіцієнт 1,0 для чоловіків; 0,85 для жінок) }\end{array}$ & 123 Вт/людину \\
\hline Тепловтрати частини корпусу із стандартною системою опалення & 280,37 кВт \\
\hline $\begin{array}{l}\text { Тепловтрати частини корпусу із застосуванням системи, що пропонується } \\
\text { (значення зменшується за рахунок застосування утеплювача) }\end{array}$ & 212,21 кВт \\
\hline
\end{tabular}

Таблиця 2 - Розрахункові параметри температурного режиму будівлі [3]

\begin{tabular}{|c|c|c|}
\hline Розрахункова температура & $\begin{array}{c}\text { Номінальна } \\
\text { (підвищена } \\
\text { оптимальна), }{ }^{\circ} \mathbf{C}\end{array}$ & ${\text { B період відсутності людей, }{ }^{\circ} \mathbf{C}}$ \\
\hline Нагріву & 21 & 12 \\
\hline Охолодження & 24 & 28 \\
\hline
\end{tabular}

Таблиця 3 - Прогнозована ефективність роботи системи термоактивного утеплення

\begin{tabular}{|c|c|c|}
\hline Сезонна ефективність роботи системи & Стандартної (ККД) & Що пропонусться (СОР) \\
\hline Нагріву & 0,65 & 7 \\
\hline Охолодження & - & 6 \\
\hline
\end{tabular}

Результати дослідження. Для дослідження температурного стану будівлі із застосуванням системи термоактивного утеплення було використано програмний модуль EnergyPlus iз iнтерфейсом DesignBuilder. Задавалися постійні граничні умови другого роду на поверхнях:

- температура внутрішніх стін $+23{ }^{\circ} \mathrm{C}$;

- температура світлопрозорих огороджуючих конструкцій $+5{ }^{\circ} \mathrm{C}$.

- температура зовнішньої поверхні перекриття дорівнює температурі зовнішнього середовища. 
- $\quad$ температура підлоги на грунті в межах $+10 \ldots+15^{\circ} \mathrm{C}$.

На рисунку 4 представлено результати CFD моделювання у вигляді розподілу температури всередині об’єкту дослідження (поточна частина корпусу) при застосуванні системи термоактивного утеплення.

Аналіз представлених даних на рис. 4 показує, що найнижча температура повітря спостерігається в межах світлопрозорих огороджуючих конструкцій. Також варто зазначити, що температура в межах вікон $\left(0,3 \ldots 0,4\right.$ м) від габаритного розміру вікна дещо знижується $\left(16 \ldots 18{ }^{\circ} \mathrm{C}\right)$. Температура внутрішньої поверхні стіни становить близько $23{ }^{\circ} \mathrm{C}$. При цьому, середньоінтегральна температура в приміщеннях 3 постійним перебуванням людей підтримується в допустимих межах $20^{\circ} \mathrm{C}$. В приміщеннях із тимчасовим перебуванням людей (коридори, хол) температура має значення в $17,35{ }^{\circ} \mathrm{C}$, що є припустимими значеннями згідно з діючими нормами [3].

Аналіз даних по розподілу швидкості в приміщеннях корпусу, які представлені на рис.5 показав, що зони локального збільшення швидкості потоку повітря розташовані поряд 3 світлопрозорими огороджуючими конструкціями, які мають найменший термічний опір та відповідно температуру. Стіни 3 північного фасаду будівлі також мають зони із збільшеною швидкістю повітря, тому для компенсації підвищених тепловтрат на даних фасадах, необхідно збільшувати температурний напір у відповідних контурах системи.

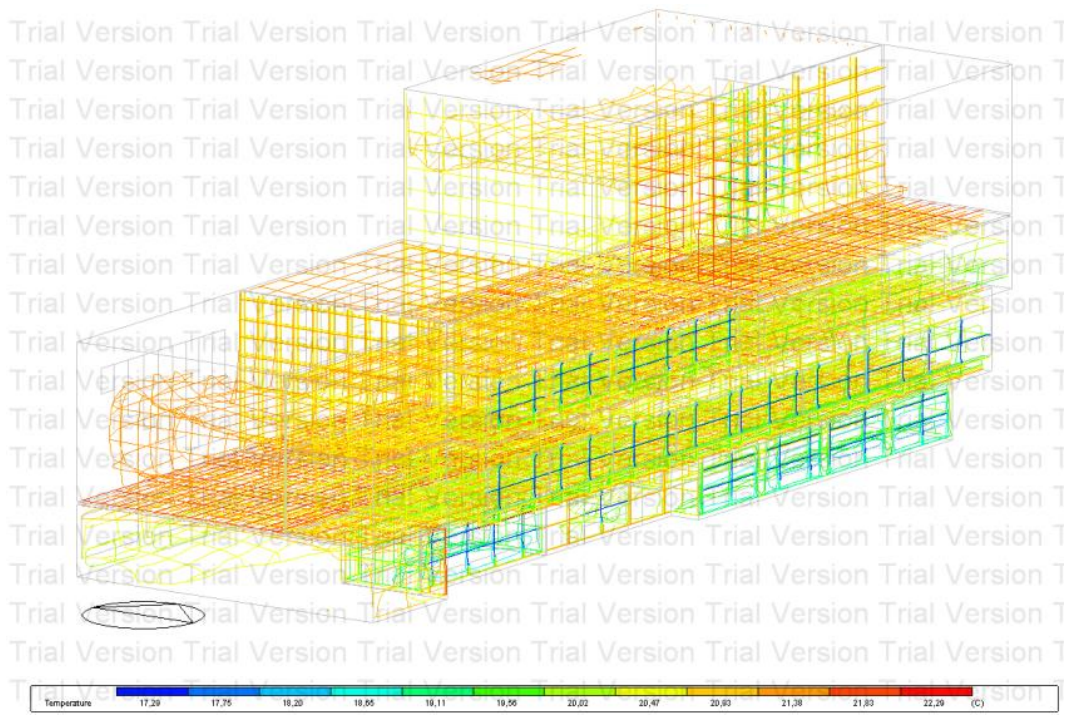

a) розподіл температури (3D контури)

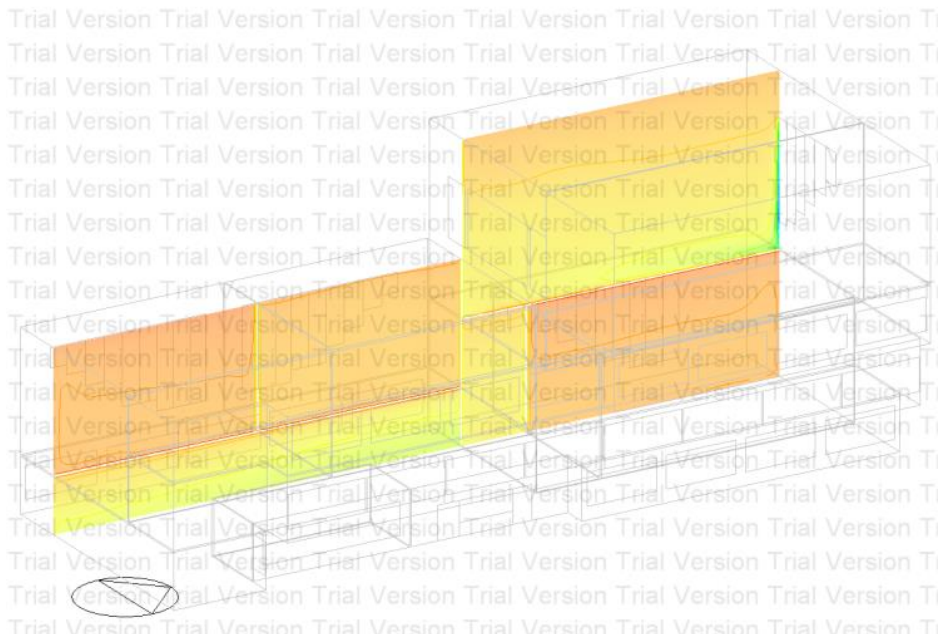

б) розподіл температури в перетині

Рисунок 4 - Розподіл температури повітря в об’єкті дослідження 


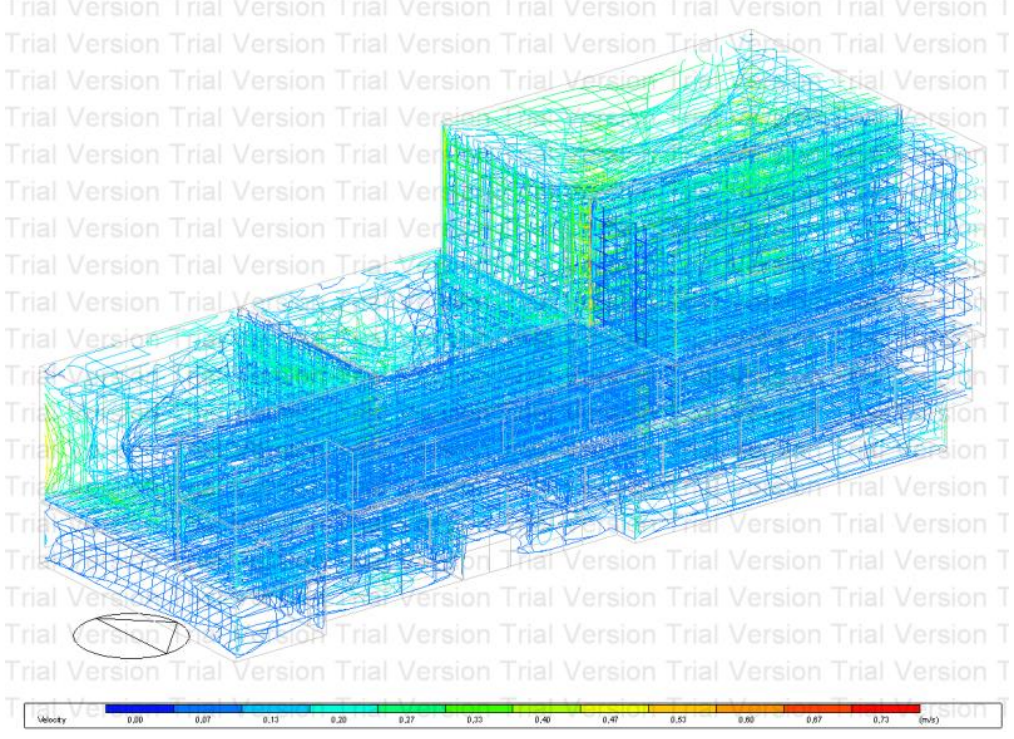

Рисунок 5 - Розподіл швидкості повітря в об’єкті дослідження

На рис. 6 представлено розподіл навантаження системи опалення об'єкту дослідження протягом всього 2016 року. Результати отримано на підставі даних про погодні умови з кроком в 1 день, що надані World Meteorological Organization (Всесвітня метрологічна організація) [4]. Середньорічні витрати енергії на опалення складають близько 30000 кВт·год, а локальні екстремуми навантаження пов'язані з гнучкістю системи та передбаченим зменшенням теплового навантаження системи в період відсутності людей у приміщеннях.

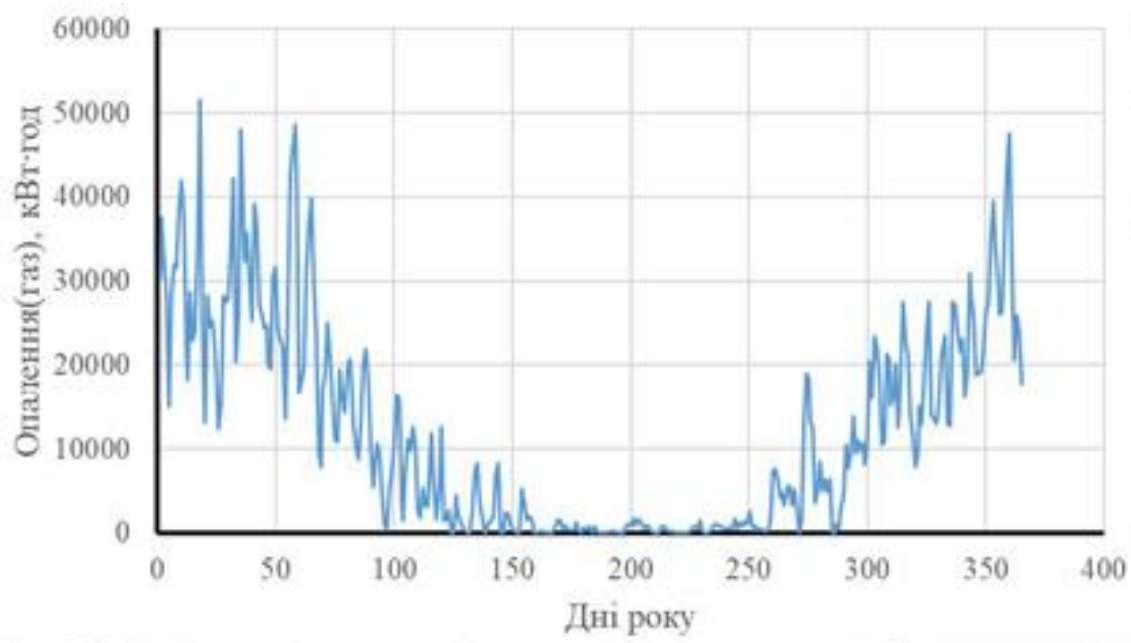

Рисунок 6 - Розподіл витрати теплової енергії протягом 2016 року при використанні стандартної системи опалення

На рис.7 показано розподіл навантаження системи опалення об'єкту дослідження протягом 2016 року при застосуванні системи термоактивного утеплення. Як показує аналіз отриманих даних середньорічні витрати енергії на опалення в цьому випадку складають близько 3500 кВт·год. Таким чином, витрати приведеної енергії на опалення приміщень об'єкту фактично зменшуються у 8 разів. Тобто фактично теплоспоживання будівлі не зменшується у 8 разів, оскільки тепловий насос генерує теплову енергію із значно вищим СОР (6.5 ..7), його електрична потужність при цьому нижче, ніж для звичайних умов експлуатації. Це пов'язано також із використанням низькотемпературної системи опалення 3 тепловим насосом. Оскільки теплова потужність, що генерує тепловий насос, залежить від різниці температур між конденсатором та випарником, електрична потужність для даної системи складає 25 кВт (за стандартних значень COP B0/W35 4.7 згідно з EN14511 [5] можна покрити лише 100 кВТ навантаження). 


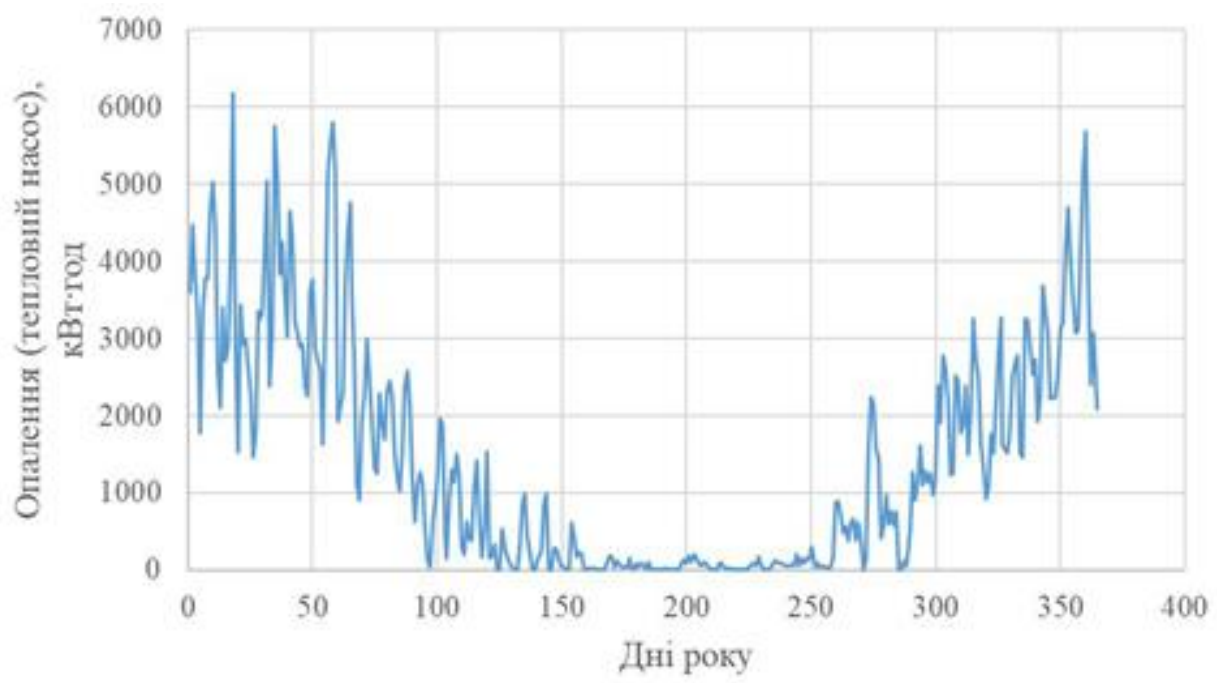

Рисунок 7 - Розподіл витрати енергї на опалення протягом 2016 року при використанні системи термоактивного утеплення

На рис.8 представлено зміну навантаження системи кондиціювання протягом дня 15 липня 2016 року, так як в цей день згідно даним, які надані World Meteorological Organization [4], спостерігалась максимальна температура повітря. Пікове значення сягає 160 кВт потужності в момент пуску системи. При виході системи на номінальний режим роботи спостерігається спад навантаження, що пов'язано із залежністю від погодних умов конкретного регіону [4]. При розрахунку буферні акумулятори не враховувались, оскільки їх завдання - максимально зсунути час генерації теплоти в нічний період, коли електроенергія дешевша.

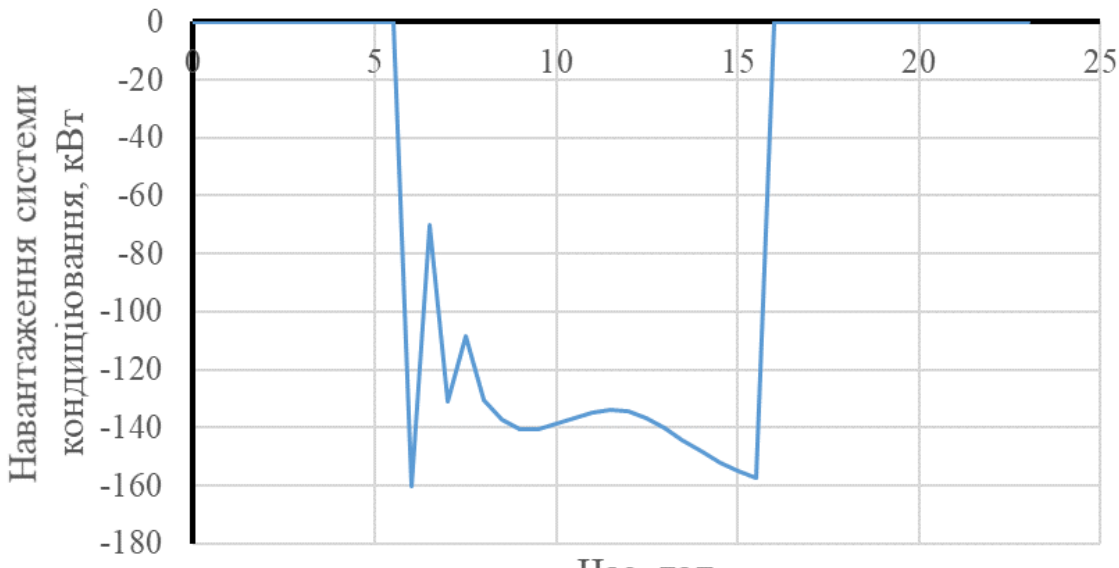

Час, год

Рисунок 8 - Розподіл навантаження системи кондиціювання при використанні системи термоактивного утеплення протягом дня (15 липня 2016 року)

\section{Висновки.}

1. Описано схемне рішення роботи системи термоактивного утеплення із застосуванням теплового акумулятора та роботи системи в нічний час за зниженим тарифом в комплексі із тепловим насосом типу сольовий розчин-вода.

2. Для запропонованої системи термоактивного утеплення використовуючи програмний модуль EnergyPlus iз інтерфейсом DesignBuilder отримано розподіл температур і швидкостей в будівлі. В середньому температура в приміщеннях з постійним перебуванням людей складає $20^{\circ} \mathrm{C}$. У приміщеннях із тимчасовим перебуванням людей значення температури сягає $17{ }^{\circ} \mathrm{C}$.

3. Визначені витрати енергії на опалення для двох систем (стандартної та запропонованої), в результаті показано, що система термоактивного утеплення у 8 разів менше споживає енергії в порівнянні зі стандартною системою. 


\section{ISSN 1813-5420 (Print). Енергетика: економіка, технології, екологія. 2018. № 1}

4. Отримано максимальне навантаження системи кондиціювання (160 кВт), в перерахунку на встановлену електричну потужність теплового насосу, що працює в режимі активного холоду при застосуванні системи активного утеплення вона сягатиме 26,7 кВт .

Таким чином, представлена система термоактивного утеплення $є$ оптимальним рішенням для реконструкції систем опалення, що вичерпали свій ресурс, оскільки не потребує втручання в «життєдіяльність» будівлі і забезпечує комфортні умови в приміщені протягом всього року, при цьому ефективно використовує енергоресурси.

\section{Список використаної літератури}

1. Gregor P. Henze, Primary energy and comfort performance of ventilation assisted thermo-active building systems in continental climates / Gregor P. Henze, Clemens Felsmann, Doreen E. Kalz, Sebastian Herkel // Energy and Buildings 40, 2008, p.p. 99-111.

2. Екокольт [Електронний pecypc] http://ecocolt.com/

3. ДБН В.2.5-67:2013 Опалення, вентиляція та кондиціонування. Київ, 2013, 147 с.

4. The World Meteorological Organization [Електронний pecypc] https://public.wmo.int/

5. BS EN 14511-2:2013 - Air conditioners, liquid chilling packages and heat pumps with electrically driven compressors for space heating and cooling. Test conditions.

R. Mordas, Masters

N. Lebed, Cand. Sc. (Eng.), Assoc. Prof.

National Technical University of Ukraine "Igor Sikorsky Kyiv Polytechnic Institute" MODELING OF THE HEAT CONDITION OF THE BUILDING WITH THE SYSTEM OF THERMOACTIVE INSULATION

The article describes a new heating system that is ideal for new buildings and for the reconstruction of old buildings, where the heating system has already exhausted its resource and can not be restored. The system of thermal-active insulation of heating and cooling has been reviewed, the main advantages of which are work with low-temperature heat sources (heat pumps, solar collectors, etc.). The thermal-hydraulic circuit of this system in conjunction with innovative equipment is proposed. CFD simulation of the temperature mode of the part of the building of the Heat Power Department of Igor Sikorsky KPI. Temperature fields and air speed distribution indoors are obtained, heat energy expenditure are obtained for two cases: before thermo-modernization and after its implementation. Due to the increased efficiency of heat pumps in the low-temperature mode, we have a difference in energy consumption to maintain the temperature of the building 8 times. Also this system can work as air conditioning for buildings.

Key words: thermos-active constructions, thermos-active insulation, heat supply system, thermal condition of buildings, heat pump.

\section{References}

1. P. Gregor Henze, Clemens Felsmann, Doreen E. Kalz, Sebastian Herkel "Primary energy and comfort performance of ventilation assisted thermo-active building systems in continental climates" Energy and Buildings vol. 40, pp. 99-111, 2008.

2. Ecocolt [Online] http://ecocolt.com/

3. DBN V.2.5-67: 2013 Heating, ventilation and air conditioning. Kyiv, 2013, p. 147.

4. The World Meteorological Organization [Online] https://public.wmo.int/

5. BS EN 14511-2:2013 - Air conditioners, liquid chilling packages and heat pumps with electrically driven compressors for space heating and cooling. Test conditions. 
P.В. Мордас, магистрант

Л.Н.Лебедь, к.т.н., доцент

Национальный технический университет Украины «Киевский политехнический институт имени Игоря Сикорского» МОДЕЛИРОВАНИЕ ТЕПЛОВОГО СОСТОЯНИЯ ЗДАНИЯ С СИСТЕМОЙ ТЕРМОАКТИВНОГО УТЕПЛЕНИЯ

В статье описано новую систему теплоснабжения, которая может использоваться как для новых домов, так и для реконструкции старых зданий, где система отопления уже исчерпала свой ресурс и не подлежит восстановлению. Рассмотрено систему термоактивного утепления отопления и охлаждения, основными преимуществами которой является работа с низкотемпературными источниками теплотьл (тепловые насосы, солнечные коллекторы и др.) Предложено теплогидравлическую схему работы данной системы в сочетании с инновачионным оборудования. Проведено CFD моделирование температурного режима части корпуса теплоэнергетического факультета КПИ им. Игоря Сикорского.. Получень температурные поля и распределения скорости воздуха в помещении, расходы тепловой энергии для отопления помещений в двух случаях: до термодернизации и после ее выполнения. В связи с возросшей эффективностью работы тепловых насосов в низкотемпературном режиме имеем разнииу в расходе энергии на поддержание температурного состояния здания в 8 раз. Характерной особенностью данной системы также является возможность работы в режиме кондиционирования помещений.

Ключевые слова: термоактивные конструкции, термоактивное утепление, система теплоснабжения, температурное состояние зданий, тепловой насос.

Надійшла 15.03.2018

Надійшла 15.03.2018

УДК 622.276

Л.К. Лістовщик, канд. техн. наук, доц., ORCID 0000-0003-3413-1802

О.В. Лотонова, студентка.

Національний технічний університет України «Київський політехнічний інститут імені Ігоря

Сікорського»

\section{ЕНЕРГООЩАДНА СИСТЕМА ЗАПОБІГАННЯ ПРОЦЕСУ ВІДКЛАДЕННЯ ПАРАФІНІВ НА СТІНКАХ НАФТОВОЇ СВЕРДЛОВИНИ}

\footnotetext{
Представлено результати аналітичних досліджень системи обігріву труби НКТ з метою запобігання відкладення парафінів на ї̈ стінках з використанням як електрокабелю, так $і$ нагрітого контуру теплового насосу. Проведено аналіз результатів та вибрано спосіб нагріву труб $з$ використанням теплового насосу.

Доведено, щу при використанні теплового насосу для нагрівання труби, порівняно з використанням електрокабелю, відбувається значне скорочення енерговитрат $і$ грошових витрат на придбання електроенергії.
}

Ключові слова: нафтова свердловина, тепловий насос, парафінова пробка, кабель для нагріву 